\title{
TELENOVELA E ETNICIDADE NEGRA: ESTUDOS DE RECEPÇÃO NO QUILOMBO URBANO DA FAMÍLIA SILVA
}


TELENOVELA E ETNICIDADE NEGRA: ESTUDOS DE RECEPÇÃO NO QUILOMBO URBANO DA FAMÍLIA SILVA ${ }^{1}$

Resumo: $O$ artigo é fruto de reflexões iniciais, surgidas a partir de entradas em campo da pesquisa empírica no primeiro quilombo urbano brasileiro, o da Família Silva. O objetivo da discussão é compreender a relação desses sujeitos com os meios de comunicação de massa, principalmente as telenovelas, verificando suas apropriações e percepções sobre personagens negros presentes neste produto televisivo.

Palavras chave: Recepção; Mediações culturais; Telenovela brasileira; Representação; Etnicidade negra

\section{TELENOVELA BRASILEÑA Y ETNIA NEGRA: ESTUDIOS DE RECEPCIÓN EN LO QUILOMBO URBANO DA FAMILIA SILVA}

Resumen: El artículo es resultado de una reflexión preliminar, que surge de las entradas en el campo de la investigación empírica en el primer quilombo urbano brasileño, la Familia Silva. El propósito del debate es entender la relación de estas personas con los medios de comunicación, especialmente las telenovelas brasileñas, revisando sus créditos y percepciones acerca de los personajes negros presentes en este producto televisivo.

Palabras Clave: Recepción, Mediaciones culturales; Telenovela brasileña; Representación; Etnia negra

\section{BRAZILIAN SOAP OPERA AND BLACK ETHNICITY: RECEPTION STUDIES IN URBAN QUILOMBO OF SILVA FAMILY}

Abstract: The article is the result of initial reflections, arising from entries in the field of empirical research in the first Brazilian urban quilombo, the Silva Family. The purpose of the discussion is to understand the relationship of these subjects with the mass media, especially the Brazilian soap operas, checking its appropriations and perceptions about black characters present in this television product.

Keywords: Reception; Cultural Mediations; Brazilian soap opera; Representation; Black ethnicity

1 Artigo baseado em paper apresentado no XI Congresso da Associação Latino-Americano de Pesquisadores da Comunicação (ALAIC): La investigación en comunicación en América Latina: interdisciplina, pensamiento crítico y compromiso social. - GT Estudos de Recepção. UDELAR/ Montevidéu/UY - 2012. 


\section{CONSIDERAÇÕES INICIAIS}

O artigo trata de uma discussão a respeito das questões étnicas a partir da experiência de uma comunidade quilombola urbana, com um olhar do Campo da Comunicação, numa articulação de diálogo com a Antropologia. Pretendemos entrelaçar teorias sobre os grupos étnicos com nossa pesquisa empírica, com a perspectiva da comunicação, cujo objetivo principal é averiguar a relação daqueles sujeitos com um meio de comunicação de massa, neste caso, o gênero telenovela. A priori, verificamos quais as apropriações e percepções daqueles sujeitos com as narrativas e personagens das telenovelas, gênero televisivo mais assistido no local.

Delimitamos nossas observações empíricas apenas na coletividade negra urbana, conhecida como quilombo da Família Silva, primeira desta categoria reconhecida no Brasil por órgãos federais, localizada no bairro Três Figueiras, um dos espaços mais valorizados da capital gaúcha. O território abriga, há mais de 60 anos, descendentes de "remanescentes quilombolas", oriundos do interior do estado. Atualmente, a comunidade é chefiada por seis filhos da $2^{\mathrm{a}}$ geração da família, sendo que já está na $4^{a}$ geração de descendentes dos primeiros moradores do local. A coletividade ficou conhecida no país inteiro por sua luta pela permanecia naquelas terras ao evocar o Artigo 68 da Constituição Federal de 1988, que estabelece a propriedade definitiva das terras aos descendentes de quilombolas que as estejam ocupando, devendo o Estado emitiros títulos de posse. O acontecimento motivou a discussão sobre o pleito étnico-racial no contexto brasileiro. Entretanto, colocou em pauta o conceito para "remanescentes de quilombo", uma vez que outrora esse Artigo foi um "dispositivo mais voltado para o passado e para o que idealmente teria 'sobrevivido' sob a designação formal de 'remanescentes' das comunidades de quilombos" (ALMEIDA, 2002, p. 46).

Para refletirmos sobre as questões sob o viés comunicacional, tomamos como ponto de referência os estudos de recepção midiática, uma vez que colocam os sujeitos e seus contextos com principais agentes da pesquisa empírica. Buscamos no modelo de codificação/decodificação, de Stuart Hall (2003), um dos nossos aportes para pensar apropriações dos sujeitos com a mensagem televisiva e se há relação desse processo decorrente das especificidades do contexto étnico. Na perspectiva do referido autor, ele indica que há uma leitura "dominante" ou "preferencial", onde o sentido da mensagem é decodificado segundo as referências da sua construção; uma leitura "negociada", em que o 
sentido da mensagem entra em negociação com as condições particulares dos receptores; e, por fim, uma leitura de "oposição", que se dá quando o receptor entende a proposta dominante da mensagem, mas a interpreta como estrutura de referência alternativa.

No entanto, essa proposta de Hall (2003) não explicita enfaticamente o entorno cultural como um dos principais fatores a serem levados em consideração para estudar a recepção midiática com os grupos sociais. No caso dos moradores do quilombo da Família Silva, seu contexto passou por um significativo processo de etnogênese (BANTON, 1977), tendo sua identidade étnica ligada à organização social (BARTH, 2000). Nesse ponto, os avanços dos estudos culturais latino-americanos dão subsídios para pensar a relação entre contexto étnico e meios de comunicação eletrônicos, principalmente, a partir da concepção das "mediações comunicativas da cultura", de Jesus Martín-Barbero (1987; 2003), por meio de seus "mapas noturnos".

Além da contribuição teórica das mediações culturais supracitadas, tomamos como referencial teórico-metodológico as experiências de pesquisas brasileiras de Jacks e Capparelli(2006), Leal (1986) eLopes et al(2002). Esses estudos são de trabalhos empíricos relacionando grupos famílias e televisão, contudo não têm como enfoque principal as questões étnicas de comunidades negras. Nos procedimentos metodológicos, tendo em vista ser um estudo alinhado à pesquisa de recepção midiática e considerando também as limitações decorrentes da entrada em campo, seguimos as experiências dos estudos que tomamos como referências e partimos de um método qualitativo de pesquisa, com perspectiva etnográfica e com o uso de técnicas como a observação participante e a entrevista semi-estruturada (GUBER, 2001; CÁCERES, 1998).

\section{QUILOMBO URBANO DA FAMÍLIA SILVA}

O quilombo da Família Silva configura-se num grupo familiar de afrodescendentes que reside, há mais de 60 anos, em uma área de aproximadamente meio hectare, no bairro Três Figueiras, na cidade de Porto Alegre. Segundo o laudo antropológico utilizado para legitimar a descendência daqueles sujeitos perante os órgãos públicos federais, a coletividade foi originalmente composta por um casal, cuja descendência constitui-se atualmente num grupo de cerca de 30 pessoas, isto é, indivíduos ligados entre si por casamento ou consangüinidade: dos onze filhos do casal apenas seis residem no local com seus res- 
pectivos cônjuges, filhos, netos e sobrinhos de irmãos falecidos(CARVALHO; WEIMER, 2004). A partir das informações obtidas pelos quilombolas, pudemos produzir o genograma familiar da coletividade (Figura 1), ficando na primeira e na segunda geração.
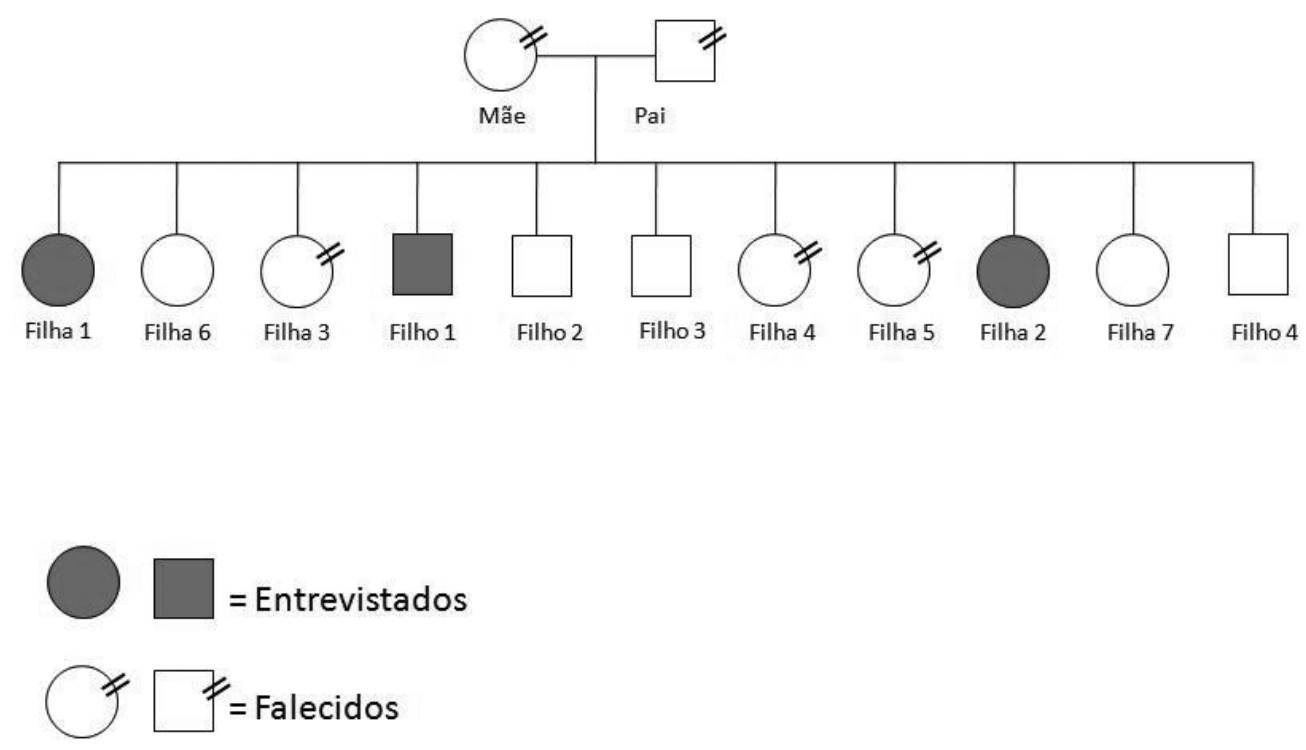

Figura 1: Genograma da Família Silva.

Fonte: Dados da pesquisa.

Com relação ao perfil de seus atuais moradores, entre os adultos, a maior parte tem apenas o primeiro grau completo em virtude de uma política assistencial do Colégio Anchieta² que, na década de 1960, oferecia aos moradores pobres da região, o ensino fundamental gratuito. As ocupações profissionais dos quilombolassão, no geral, mal-remuneradas e seus empregadores em sua maioriaresidem nas áreas próximas: as mulheres trabalham em serviços domésticos e os homens como vigias e jardineiros da luxuosa vizinhança ou no CountryClub. As crianças passam meio turno em uma escola pública dos arredores e o restante do dia no pátio do terreno sob os cuidados dos adultos que estão em casa naquele momento. O quilombo citadino é composto por sete residências construídas de compensado de madeira, teto de zinco, com dois ou três cômodos, com ligações clandestinas de luz e água.

A origem dos atuais moradores ${ }^{3}$ deve-se a uma descendência de negros

2 Escola privada, de ensino fundamental e médio, de confissão jesuíta.

3 Referência aos membros da $2^{\text {a }}$ geração. 
provenientes de cidades do interior do Rio Grande do Sul: os avós maternos são naturais de São Francisco de Paula e Cachoeira do Sul, sucedidos por seus pais, ambos de São Francisco de Paula, na ocupação do território e na perpetuação de seus modos de vida e organização social. Foi após a instalação no local, hoje conhecido como bairro Três Figueiras, que possibilitou aos seus antepassados territorializarem-se na primeira metade do século passado.

Antes da obtenção do título de primeiro quilombo urbano do país, os órgãos municipais de Porto Alegre consideravam a Família Silva como mais uma “ocupação irregular" da cidade ou confundida com a Vila Beco do Resvalo, que se localiza ao lado, mas com diferenças importantes entre os dois grupos, de ordens territorial, espacial, histórica e étnica. A presença de cercas e marcos de concreto colocados por seus antepassadosdefine a área de domínio em relação ao entorno. Casas dispostas no pátio de forma espaçada, em função da lógica familiar interna, ajudaram a comprovar a presença dessas pessoas há décadas no local.

Historicamente, a ocupação do território foi iniciada com a primeira casa, construída pelo avô materno, no início da década de 1940. Hoje se encontram no local seis residências. Com o passar dos anos, entre os "Silva" as alianças matrimoniais se realizaram com outras pessoas negras do entorno com as quais eles mantêm intensa sociabilidade em função da proximidade, do trabaIho ou da amizade.

Apesar de terem feito duas tentativas frustradas para a obtenção definitiva das terras através da Justiça estadual, somente a partir de 2002, o quilombo passou a protagonizarde forma mais organizada a luta pela regularização fundiária daquele território sob a chancela de comunidade remanescente de quilombo. Neste momento, aquela coletividade se mostrou um exímio exemplo de organização eficiente para resistência ou conquista de espaços e organização política (WEBER, 1991). Após os trinta anos de tentativas de legitimação da posse por meio do mecanismo legal de "usucapião" sem sucesso e sob a iminência de ser despejada judicialmente pelos possíveis donos da área, a Família Silva - com a ajuda do movimento negro gaúcho - invocou seus direitos previstos nas Constituição Federal.

Nesta questão pela posse da terra, em função de um contexto singular citadino, o conflito adquiriu outros contornos. Com a ajuda de entidades do movimento negro e outras entidades da sociedade, os sentidos e símbolos étnicos começaram a ser incorporados à luta da Família Silva, pois o fato de se tratar de 
uma população constituída apenas por negros sulinos fez com que aquele grupo ganhasse maior evidência. Sobre essa questão específica da constituição de uma etnicidade, Banton (1977, p. 166) afirma que:

A formação de uma minoria étnica depende de uma crença existente entre os membros da minoria de que a natureza da sua ascendência comum exige ou justifica a sua junção e ela seria mais fácil se a maioria compartilhasse também, por sua vez, essa mesma crença.

A ideia de etnicidade defendida por este autor diz respeito ainda a uma qualidade compartilhada, com a particularidade dos membros terem consciência de pertencer ao grupo e, no caso da Família Silva, ainda se tornarem referência para outras coletividades similares e vários segmentos sociais.

Com uma breve explicitação do contexto sócio-histórico da Família Silva, oferecemos alguns elementos concretos para pensar a questão da identidade étnica para um estudo com comunidade quilombola. Pretendemos averiguar se os sujeitos fazem inferências sobre suas realidades, considerando o modo como os negros são apresentados nas telenovelas brasileiras e, assim, traçar paralelos e questionamentos sobre representações sociais,etnicidade e meios de comunicação.

\section{MEDIAÇÕES COMUNICATIVAS DA CULTURA}

Ao propor discutir as possíveis relações da identidade étnica de uma comunidade quilombola urbana com a recepção de telenovelas brasileiras, tomamos como referencial teórico os estudos sobre recepção midiática, referendados nos estudos cultuais (tanto ingleses quanto latino-americanos). No contexto de América Latina, as pesquisas no campo da recepção midiática surgiram como forma de deslocar o eixo das discussões até então hegemônicas no Campo da Comunicação centradas na transmissão dos grandes meios de comunicação. Entre os defensores desse posicionamento há aqueles que pensavam que a "pesquisa em comunicação não é a que focaliza estritamente os meios, mas a que se dá no espaço de um circuito de consumo da cultura midiática" (JACKS; ESCOSTEGUY, 2005, p. 39).

Com essa perspectiva em vista e sabendo do contexto étnico-cultural dos sujeitos desta pesquisa, partimos de uma hipótese teórica que é referendada em estudos de recepção que consideram as mediações responsáveis pelo pro- 
cesso de assimilação, rejeição, negociação, resistência etc., a que estão sujeitas as mensagens televisivas, sendo as identidades apresentadas por este meio de comunicação incluídas na ideia de mensagem. Dessa forma, o foco para refletir sobre a relação dos media com a sociedade é deslocado para os receptores, o que na perspectiva de Martín-Barbero (1987) é pensar a comunicação a partir das mediações e não somente dos meios.

Pelo pensamento de Martín-Barbero (1987; 2002; 2003), a recepção midiática é um momento do consumo cultural, sendo este uma categoria que abarca os processos de comunicação e recepção dos bens simbólicos. Assim, ele já descarta o axioma de que a recepção se constitui somente em uma relação direta entre dois pólos distantes: o produtor e o receptor. Ou seja, a recepção é vista aqui como parte de um processo de produção de sentido através das mediações.

Por tanto, iremos nos valer de questões que auxiliem na reflexão sobre a configuração da ideia de mediações, tendo como ponto de partida trabalhos empíricos (JACKS, 1999; LOPES et al 2002), críticos dessa perspectiva (BOAVENTURA; MARTINO, 2008; SIGNATES, 2006) e nas próprias redefinições propostas por Martín-Barbero (2002; 2003, 2009a). Isso se deve, pois a teoria das "mediações comunicativas da cultura" nos remete a paradoxos e a ambigüidades que mobilizam a comunicação no processo de negociação de sentido, o que impossibilita pensar numa definição única sem sermos imprecisos, uma vez que dentro da própria obra do filósofo espanhol encontramos tais indefinições.

Segundo o pensamento inicial de Martín-Barbero (1987), essas mediações são os lugares que estão entre a produção e a recepção. Nesse sentido, a comunicação pensada a partir da perspectiva das mediações deve levar em consideração o entendimento de que entre estes dois pontos do processo comunicativo há um espaço em que a cultura cotidiana se dinamiza. É por essa linha de raciocínio que Martín-Barbero (1987, p. 233), inicialmente, sugeriu três hipóteses de mediação que interferem e alteram a maneira como os receptores recebem os conteúdos midiáticos. São elas: cotidianidade familiar, temporalidade social e competência cultural.

Mesmo adotando essa perspectiva teórica das mediações de Martín-Barbero, na prática da pesquisa em comunicação, é evidente que os estudos sobre recepção se fazem a partir de diferentes marcos metodológicos, com o objetivo de se compreender com maior eficácia a apropriação das mensagens midiáticas pelos receptores. Mas consideramos que essa questão não pode ser realizada excluindo as relações de poder existentes nos discursos dos media e 
nas interações sociais como um todo.

É a partir dessas contribuições que pretendemos ter subsídios para estudar a recepção numa comunidade negra urbana, levando em consideração as percepções que os sujeitos fazem da presença dos negros nas narrativas das telenovelas, buscando refletir também a respeito das especificidades referentes aquele contexto étnico.

\section{ENTRADA EM CAMPO NO QUILOMBO DA FAMÍLIA SILVA}

A escolha do quilombo da Família Silva como campo de pesquisa, deve-se principalmente ao fato dele ser o primeiro quilombo urbano do Brasil,com titulação reconhecida pelo Governo Federal; pela vanguarda e posição de destaque em relação ao movimento negro gaúcho; e por estar situado num contexto étnico em que a contribuição do negro na formação da sociedade local passou por um processo de invisibilização, conforme indica Ruben Oliven (1996). Nossos primeiros contatos com os moradores do local foram através do blog 4 do quilombo, pesquisas realizadas pela Universidade Federal do Rio Grande do Sul e reportagens de arquivos de periódicos locais. Com isso, verificamos, logo de início, que a presença do movimento negro e de outros mediadores - como os pesquisadores e a imprensa-, são fundamentais na medida em que respaldam e até mesmo influenciam na organização política desses grupos em termos étnicos, com vistas a garantir seus direitos sobre as áreas ocupadas(CARVALHO, 2006).

A partir das entradas em campo, pudemos compreender melhor a "ritualidade" local e definir, realmente, a televisão e a telenovela como o media e gênero, respectivamente, a serem estudados com aqueles receptores. Mesmo sendo casas simples e com ligações clandestinas de energia, as seis residências possuem televisores, em alguns casos, de última geração (tela plana, acima de 40 polegadas),sendo a principal diversão das famílias durante a semanaquando retornam do trabalho. Esse tipo de ambiente que conta coma presença do aparelho de TV em casas humildes não é exclusividade daquele quilombo urbano, pois no Brasil muitas moradias não possuem geladeira ou camas para todas as pessoas, mesmo assim, há um televisor, onipresente, posto em local

4 O blog - que pode ser acessado em <http://quilombofamiliasilva.blogspot.com/> - é atualizado por um ativista do movimento negro, conhecido com Jader, que serviu para que chegássemos à localidade. 
de destaque, se tornando o principal eletrodoméstico. Algo similar foi verificadoem pesquisas anteriores, principalmente, no estudo realizado no quilombo maranhense Itamatatiua onde o aparelho de televisão desde sua chegada se tornou o principal móvel das residências, consubstanciando ainda naquele contexto aspectos da identidade cultural quilombola a partir das ornamentações adjacentes ao televisor (GRIJÓ, 2010).Em sua pesquisa de campo realizada no Rio Grande do Sul, há três décadas, Ondina Fachel Leal (1986, p. 33) já havia percebido essa valorização da televisão, destacando que: "As casas na vila têm sempre a televisão como peça de frente".

Da mesma forma, a programação televisiva ajuda a conduzir a temporalidade social dos sujeitos, pois a rotina noturna está alicerçada também no horário dos programas que eles geralmente assistem pela televisão. Neste caso, as pessoas adultas têm acesso principalmente à programação noturna da TV Globo (e de sua afiliada no estado a RBS TV), que veicula no período das 18 às 22 horas, três telenovelas ${ }^{5}$ e dois telejornais ${ }^{6}$. Segundo foi possível averiguar pelas respostas obtidas nas entrevistas e observaçõesin loco, as pessoas sentam-se à sala apenas no momento de transmissão das telenovelas, pois nos telejornais elas executam outras atividades concomitantes e por isso apenas os ouvem.

A presença da televisão na vida daqueles sujeitos está presente desde a infância, pois seus pais, os primeiros moradores do quilombo, já possuíam aparelho de TV em casa. Todas as gerações posteriores podem ser consideradas telespectadoras da programação televisiva, o que lhes permitiu ter um maior entendimento sobre a gramática da televisão,e assim construir uma memória televisiva, algo que não encontramos frequentemente nas comunidades quilombolas rurais. Nestaso aparelho de TV somente foi introduzido após a chegada da energia elétrica (GRIJÓ, 2010), a partir de ações sociais do Governo Federal como o Programa Luz para Todos7, que desde sua criação em 2003 já beneficiou quase 12 milhões de pessoas moradoras de zonas rurais.

Apesar de termos observado pessoas de todos os gêneros e faixas etárias sentarem-se à noite em frente o aparelho de TV para assistir às telenovelas, os

5 No período do levantamento: Cordel Encantado(18h), Morde e Assopra(19h) e Insensato Coração (21h).

6 RBS TV, produção local da emissora homônima e o Jornal Nacional, da Rede Globo.

7 <http://www.palmares.gov.br/2012/02/programa-luz-para-todos-beneficiara-comunidadesquilombolas/>. Acesso em 01/11/2012. 
moradores do sexo masculino se disseram mais telespectadores da programação esportiva e dos filmes. Entretanto, presenciamos os homens e os outros membros da família (mulheres, adolescentes e crianças) no momento de assistência das telenovelas, assim como tinham conhecimento do que era transmitido atualmente e memória de produções de anos anteriores: "Aqui, os homens ligam mais pra filme e quando passa jogo na TV. Novela a gente vê mais acompanhando os outros familiares quando estão assistindo também"8. Neste âmbito, detectamos uma relação de gênero, dentro desse contexto étnico, como será evidenciado também no discurso das mulheres, como exporemos adiante.

Com as observações, relatos em diário de campo e entrevistas com moradores da comunidade, para o presente artigo (e de acordo com o momento em que a pesquisa se encontra) fixamos nossa análise nas entrevistas com três sujeitos da segunda geração da Família Silva. Além desses, outros três irmãos residem na comunidade; uma irmã mora no bairro Pinheiro, na periferia de Porto Alegre; e outros quatros irmãos são falecidos. Esses 11 filhos que compõem a segunda geração da família foram mapeados até o momento, mas cabe destacar que há a terceira e a quarta gerações, que ao todo chegam a 60 pessoas, universo da população que será considerada nas etapas seqüentes do estudo em andamento.

\section{PERCEPÇÕES DA ETNICIDADE NAS TELENOVELAS}

No quilombo da Família Silva, a televisão é o principal meio de informação das pessoas, entretanto não tem a exclusividade dessa função. Elas têm contato, em menor escala, com jornais populares, rádio e as gerações mais novas frequentemente acessam à Internet através de lan houses. Nesse aspecto, a presente proposta de trabalho de recepção com esses sujeitos leva em consideração apenas suas percepções a respeito das representações sociais dos negros realizadas nas telenovelas, gênero televisivo de maior difusão na comunidade.

Assim, a partir de uma leitura flutuante das entrevistas com moradores do quilombo em relação à percepção da presença de personagens negros nas telenovelas brasileiras, pudemos agrupar a questão em três momentos: as representações do passado, as mudanças recentes e a atual representação. Nossa análise, parte principalmente de um paralelo entre as entrevistas com duas ir-

8 Entrevista com Filho1. 
mãs de 50 anos e 40 anos, cujos nomes não serão apresentados aqui como forma de preservar suas identidades, sendo identificadas apenas por Filha 1 e Filha 2, respectivamente. A escolha das duas deve-seainda porque apesar de serem da mesma família, viverem no mesmo contexto sócio-cultural, partiIham, em muitos momentos, de leituras diferencias das telenovelas.

Assim, as entrevistadas percebem a forma subalternizada como os negros foram representados nas telenovelas, ao mesmo tempo em quem reconhecem que houve, mesmo timidamente, a presença de negros nas produções ao longo dos anos. Como é o caso da Filha 1, que ainda hoje tem em sua memória "Mãe Dolores", uma das personagens mais famosas deO Direito de Nascer(TV Tupi, 1964), veiculada na década de 1960, a primeira a ter grande destaque numa produção televisiva, mesmo tendo um tom de subserviência incondicional em relação aos personagens brancos.

A novela mais antiga que lembro é 'O Direito de Nascer'... eu lembro que assistia quando era bem nova. Era ainda em preto e branco... aqui a gente já tinha TV. Eu lembro de uma negra que sabia de tudo na novela e a gente gostava muito dela. Mas isso faz muito tempo. Ela era boa e todos gostavam dela. Ela trabalhava para os brancos, mas sabia da via de todos eles e era engraçada. Era na época que nem tinha TV aqui, a gente via na casa de uma vizinha, só depois que papai comprou a nossa aqui e pudemos ver em casa. ${ }^{9}$

Por um lado, para a Filha 1, a lembrança da personagem está mais ligada a uma questão de classe, por ser uma empregada doméstica carismática, com influência na vida dos outros personagens brancos, sem qualquer menção à relação étnica da negritude. Por outro, nas lembranças das telenovelas antigas pela quilombola Filha $\mathbf{2}$ há uma percepção mais ligada às questões étnicas. Inclusive, questionando a presença dos negros apenas como personagens destinados para alguns tipos de papéis como escravos e empregadas domésticas.

Eu lembro que na época de minha mãe, quando a gente assistia novela e tinha negro, era tudo escravo, só viviam nas senzalas. Ou então, trabalhavam como empregas... não tinha outro tipo de ocupação. Agora, de um tempo prá cá que eu vejo negro em outras profissões, aparecendo mais nas novelas.

9 As falas das entrevistadas serão reproduzidas conforme foram ditas. 
Ao termos contato com o cotidiano das duas mulheres, identificamos que a formação política das duas configura-se em mediação influente na recepção das telenovelas, pois a Filha 1, por ser uma das irmãs mais velha da $2^{a}$ geração, não se envolveu com a mesma intensidade na questão do movimento negro, inclusive, foi criada sem a noção de identidade étnica tão presente na sua rotina como ocorreu na vida da Filha 2, irmã mais nova. Neste sentido, interpretamos que há uma mediação ligada à questão geracional, pois entre as duas irmãs há uma diferença de mais de dez anos. Com isso,arriscamos dizer que há leituras diferenciadas das telenovelas, mesmo estando os dois sujeitos vivendo em um contexto cultural próximo, com mediações culturais similares.

No entanto, as duas irmãs possuem observações similares sobre as mudanças na representação dos afrodescendentes nas telenovelas. Diferenciam, a partir de suas leituras, o antes e o depois em relação à presença dos negros nessas produções: "Até pouco tempo, a gente só via nas novelas os negros fazendo empregados, né? Não tinha esses papéis como tem hoje, não tinha negro rico em novela, só aparecia em coisa que não era legal"10.

A observação, na mudança de abordagem dos negros nas tramas, não significa que seja recebida por elas como algo sem qualquer ponderação ou sem questionamento sobre uma possível imagem negativa para o negro quando é representado de forma contrária ao papel de herói ou mocinho nos folhetins televisivos.

Esse foi o caso do personagem negro e vilão, Romildo Rosa (Milton Gonçalves), na telenovela A Favorita (TV Globo, 2008). Segundo Filha 2, o fato do personagem ser um homem rico e com poder foi importante para colocar o negro como um sujeito com possibilidade de ascensão social, no entanto, tinha o lado negativo do ser um vilão, o que para ela era um desprestígio para a imagem de todos os negros. Ou seja, Filha 2 considera que o fato de um personagem negro ter uma conduta incorreta socialmente e estar presente numa telenovela pode interferir na concepção que as pessoas têm de todos os afrodescendentes.

Eu lembro muito daquele Romildo Rosa... ele só incomodava as pessoas na novela. Ele achava que tinha poder, era desses políticos ricos e que acham que podem ser melhor do que as outras pessoas. Esse

10 Entrevista com Filha 2. 
era um personagem negro com destaque em novela, mas não era legal, não foi bom pros negros também. ${ }^{11}$

Entretanto, como as leituras dos receptores sobre os produtos televisivos podem ser negociadas - segundo Hall (2003), ede acordo com o modelo sobre codificação/decodificação -, o fato de uma emissora hegemônica colocar um personagem como central dentro de uma telenovela, não significa que terá aceitação irrestrita pelos próprios negros. Essa questão foi observada na recepção que as mulheres do quilombo fizeram em relação à primeira protagonista negra de uma telenovela das 21 horas, presente em Viver a Vida (TV Globo, 2009). Neste caso, a identificação que elas tiveram com a presença da personagem seguiu à própria trajetória desta dentro da trama, onde foi perdendo status de protagonista para outras personagens brancas. As mulheres quilombolas reconheceram a importância da personagem para a questão da negritude no Brasil, entretanto isso não significa que houve uma aceitação irrestrita.

Quando a Taís Araújo fez a principal da novela das oito eu gostei por que tinha uma negra com papel importante em novela. Mas da personagem na novela eu não gostei, não tinha muita graça, ficou muito apagada, não convenceu como principal. Eu esperava mais dela. ${ }^{12}$

Essa mesma leitura ocorre atualmente com a percepção delas em relação ao personagem negro de maior destaque na telenovelalnsensato Coração(TV Globo, 2011) das 21 horas, no caso o designer, profissional bem sucedido André, interpretado por Lázaro Ramos, cujo perfil de sedutor é visto de forma negativa pelas entrevistadas, seria algo que prejudica a imagem do negro perante a sociedade. Percebemos uma questão de gênero dentro dessa discussão étnica, pois a crítica em relação ao personagem centra-se muito no fato dele obter prazer sexual com mulheres e depois desprezá-las. Neste caso, a questão étnica aparece de forma mais evidente quando as entrevistadas criticam a representação desse personagem por ele apenas se relacionar, predominantemente, com mulheres brancas.

Esse negro que tem na novela das oito, eu já não gosto. Ele faz o

11 Entrevista com Filha 2.

12 Entrevista com Filha 1. 
que quer com as mulheres, não respeita nada, nada fica bom pra ele. Todo dia ele aparecia com uma branca diferente. Ou eles colocam os negros como empregados ou colocam nesse papel aí que faz coisa errada e não fica bom pros negros. ${ }^{13}$

Essa opinião é compartilhada pelas duas entrevistadas:

Acho que tem muito pouco negro nas novelas. Não tem muito negro com papel bom, só agora que eles começaram a botar uns papéis meIhores. Eu vejo agora o Lázaro Ramos na novela das oito, mas ele tá muito nojento prá mim. Acha que pode pegar as mulheres e só quer pegar mais mulher branca. Agora que voltou prá escurinha, mas antes só pegava as brancas. ${ }^{14}$

Uma importante mediação do contexto cultural como mediação da recepção da telenovela é a crítica à realidade dos negros na ficção que as entrevistadas demonstraram possuir. Elas identificam nas tramas que os afrodescendentes praticamente não presenciam as situações de preconceito e exclusão étnica com as quais elas convivem cotidianamente. Isto elas questionam, pois comparam a situação dos negros nas telenovelas com a vida real, visto que têm experiências em que presenciaram ou foram vítimas de preconceito racial. Neste aspecto, destacam sentir falta da discussão quando é retratada a vida de um afrodescendente.

Hoje, as novelas mostram que a vida dos negros é de um jeito, mas a gente aqui sabe que é diferente. Não é tudo rico, com emprego, vivendo bem, tem é racismo na vida real. A gente, que mora aqui nesse quilombo, cercado de gente rica querendo tirar a gente daqui, sabe que é diferente. ${ }^{15}$

Verificamos que o contexto de vida em coletividade também é uma forma de mediação na recepção das telenovelas. Essa questão foi notada quando as mulheres identificaram o cotidiano de uma comunidade de periferia presente na telenovela Duas Caras(TV Globo, 2007) como algo parecido com o contexto delas. Os motivos foram vários: ter um personagem central carismático, serem

13 Entrevista com Filha 1.

14 Entrevista com Filha 2.

15 Entrevista com Filha 1. 
moradores de uma comunidade pobre e alvo de preconceito e maldade dos poderosos, etc. Mesmo essa telenovela tendo entre seus temas a questão do racismo sofrido por um de seus personagens, na memória televisiva das entrevistadas o que marcou de fato foi a questão da exclusão de classe.

Eu gostava muito do Antonio Fagundes quando ele fazia o Juvenal. Era bom por que ele ajudava o pessoal da favela, por tudo que ele fazia pelo povo. Era um homem bom, líder comunitário, enfrentava as coisas que os ricos que queriam invadir a favela deles. ${ }^{16}$

Assim, a partir da exposição e análise das entrevistas com membros do quilombo da Família Silva, pudemos visualizar algumas das concepções desses sujeitos sobre a presença de negros em telenovelas brasileiras e das relações que estabelecem a partir de suas realidades. Desse modo, pudemos averiguar nas falas delas, traços das mediações culturais nas apropriações do conteúdo das telenovelas, neste caso, sobre a representação dos negros nas ficções.

\section{CONSIDERAÇÕES}

Ao iniciarmos nossas observações empíricas no quilombo da Família Silva e as possíveis relações entre a identidade étnica e os meios de comunicação, pudemos aprofundar melhor nossa reflexão a partir das respostas que obtivemos com as entrevistas e com o contato direto com os sujeitos e suas experiências. Dessa forma, por ser a telenovela o gênero televiso mais visto por aquelas pessoas, mesmo se tratando de obras de ficção, ela serviu para suscitar a discussão sobre presença do negro dentro da sociedade,contando com observações que partiram da mesma etnia. Isso por que, na "realidade" ficcional da telenovela brasileira, o negro é predominantemente retratado como indivíduo que vive sem ser alvo de preconceitos, numa produção de sentido que esconde as questões étnicas, criando um "consenso" da democracia racial brasileira, conforme já fora indicado por vários autores.

Na pesquisa empírica com os sujeitos, tivemos acesso às suas "ritualidades" com a telenovela e entendemos como esse gênero televisivo faz parte de suas rotinas, até mesmo pela falta de outras formas de diversão. Entretanto é algo para eles percebido como inerente ao cotidiano após a rotina de trabalho.

16 Entrevista com Filha 2. 
Diante disso, a partir das discussões suscitadas pelas representações da negritude nas telenovelas, por terem uma formação política do movimento negro e devido à luta pela regularização da terra, os quilombolas entrevistados fazem leituras negociadas sobre questões da negritude presentes nessas produções televisivas. Eles identificam como necessária alguma forma de representação mais fidedigna dos negros, reconhecem que há mudanças pontuais em relação aos anos anteriores, mas não consideram como totalmente positivo o destaque dado aos negros nas produções contemporâneas, pois prejudica ascaracterísticas dessa etnia prejudicando a imagem que passa a ser construída sobre eles pela sociedade.

Por fim, em suas percepções, as questões étnicas dividem espaço também com relações de classe e de gênero. Ou seja, além de identificarem a questão do negro dentro das narrativas, no discurso dos sujeitos aparecem menções a conflitos de classe, uma vez que eles presenciam essa questão em seu contexto social e questões relativas ao gênero, visto que as entrevistas discordaram da representação de personagem negro por ele tratar suas parceiras como objeto sexual. Inclusive, essas outras questões, que apareceram nas entrevistas com outras mediadoras das apropriações das representações das telenovelas, são categorias que não havíamos pensando a priori, o que de certa forma redireciona nossas próximas avaliações empíricas na localidade nos decorrer do processo investigativo, previsto para os meses seguintes.

\section{REFERÊNCIAS}

ALMEIDA, A. W. B. Os Quilombos e as Novas Etnias. In: Eliane Cantarino O'Dwyer (org). Quilombos: Identidade Étnica e Territorialidade. Rio de Janeiro: ABA - FGV, 2002.

BANTON, M. Aspectos Sociales de la Cuestión Racial.In: Cuatro declaraciones sobre la cuestión racial. Paris: UNESCO, 1971.

. Etnogênese. In: A idéia de raça. São Paulo: Edições 70/Martins Fontes, 1977.

BARTH, F. A Análise da Cultura nas Sociedades Complexas. In: LASK, T.(Org). 0 Guru, o iniciador e outras variações antropológicas. Rio de Janeiro: Contracapa, 2000.

BARTH, F. Grupos Étnicos e suas Fronteiras. In: POUTUGNAT, P.; STREIFF-FENART, J. (Org). Teorias da etnicidade. São Paulo: Editora da UNESP, 1998.

BARTH, F. Temáticas permanentes e emergentes na análise da etnicidade. In: VERMEULEN; GOVERS (org). Antropologia da etnicidade: para além de Ethnic Groups and Boundaries. Lisboa: Fim de século, 2003. 
BOAVENTURA, K. T.; MARTINO, L. C. Estudos Culturais Latino-Americanos: convergências, divergências e críticas. XXXII Congresso Brasileiro de Ciências da Comunicação. Anais. Curitiba-PR, 2009.

CÁCERES, J. G. Etnografía: El oficio de la mirada y el sentido. In: Técnicas de investigación en sociedad, cultura y comunicación. México. CNCA/ Adilson Wesley Longman, 1998.

CARVALHO, A. P. C.; WEIMER, R. A. Família Silva: Resistência Negrano bairro Três Figueiras. Laudo antropológico e histórico de reconhecimento da comunidade remanescente de quilombo Família Silva para cumprimento ao artigo 68/ADCT. FCP/PMPOA: Porto Alegre, setembrode 2004 .

CARVALHO, A. P. C.O Quilombo da “Família Silva”: Etnicização e politização de um conflito territorial na cidade de Porto Alegre/RS. Prêmio ABA/MDA Territórios Quilombolas. Associação Brasileira de Antropologia (Organizador). Brasília: Ministério do Desenvolvimento Agrário, Núcleo de Estudos Agrários e Desenvolvimento Rural, 2006.

GRIJÓ, W. P. Mídia e Cultura: um estudo da televisão e da identidade cultural no quilombo de Itamatatiua. Dissertação de mestrado em Comunicação, Cultura e Cidadania. Universidade Federal de Goiás (UFG). Goiânia: março de 2010.

GUBER, R. El investigador en el campo. In: La etnografia: Método, campo y reflexividad. Buenos Aires: Editorial Norma, 2001.

HALL, S. Da Diáspora: Identidades e mediações culturais. Belo Horizonte: UFMG/ Representações da UNESCO no Brasil, 2003.

JACKS, N. Querência: cultura regional como mediação simbólica. Porto Alegre: UFRGS, 1999.

JACKS; CAPPARELLI . TV, Família e Identidade: Porto Alegre “Fim de Século".Porto Alegre: EDIPUCRS, 2006.

JACKS, N.; ESCOSTEGUY, A. C. Comunicação e recepção. São Paulo: Editora Hacker, 2005. JACKS, N.; MENEZES, D.; PIEDRAS, E. Meios e audiências: a emergência dos estudos de recepção no Brasil. Porto Alegre: Sulina, 2008

LEAL, O. F. A leitura social da novela das oito. Petrópolis: Vozes, 1986.

LOPES, M. I. V. et al. Vivendo com a telenovela: mediações, recepção, teleficcionalidade. São Paulo: Summus, 2002.

MARTÍN-BARBERO. J. Comunicação e mediações culturais. Revista Brasileira de Ciências da Comunicação. São Paulo, v. XXIII, nº 1, jan-jun, 2000.

. De los medios a las mediaciones: comunicación, cultura y hegemonia. México: Gustavo Gilli, 1987.

- Ofício de Cartógrafo: Travesías latinoamericanas de la comunicación em la cultura. México/Santiago: Fondo de Cultura Econômica, 2002.

.As formas mestiças da mídia. Entrevista concedida à Mariluce Moura. Pesquisa FAPESP Online, edição 163, p. 10-15, setembro 2009 a. 
. Uma aventura epistemológica. Entrevista concedida à Maria Immacolata Vassalo de Lopes.Matrizes, v. 2, n. 2, p. 143-162, $2009 \mathrm{~b}$.

OLIVEN, R. G. A invisibilidade social e simbólica do negro no Rio Grande do Sul. In: LEITE, I. B. (Org). Negros no Sul do Brasil: invisibilidade e territorialidade. Florianópolis: Letras Contemporâneas, 1996.

SIGNATES, L. Estudo sobre o conceito de mediação e sua validade como categoria de analise para os estudos de comunicação. In: SOUSA, M. W. (org.). Recepção mediática e espaço público: novos olhares. São Paulo: Paulinas, 2006.

WEBER, M. Relações Comunitárias Étnicas. In: Economia e Sociedade. Vol.I. Brasília, Editora da Universidade de Brasília, 1991.

RECEBIDO EM: 05/11/12

ACEITO PARA PUBLICAÇÃO: 18/01/13

\section{Wesley Pereira Grijó}

Doutorando em Comunicação e Informação pela Universidade Federal do Rio Grande do Sul. Bolsista da Coordenação de Aperfeiçoamento de Pessoal de Nível Superior (CAPES). Mestre em Comunicação, Cultura e Cidadania pela Universidade Federal de Goiás. Bacharel em Comunicação Social pela Universidade Federal do Maranhão. Membro dos Grupo de Pesquisa no CNPq "Comunicação e práticas culturais"; Pesquisador-membro do Observatório Ibero-Americano de Teleficção (Obitel). 